\title{
Studi pemetaan kualitas batu gamping bukit tui kota padang panjang menggunakan XRF dan XRD untuk memenuhi requirement industri
}

\author{
Riam Marlina $\mathrm{A}^{1)^{*}}$, Afni Nelvi ${ }^{2)}$ \\ ${ }^{12}$ Teknik Pertambangan, Sekolah Tinggi Teknologi Industri Padang, Jln. Prof. Dr. Hamka No. 121 Tabing, \\ Padang, Indonesia \\ riammarlina@sttind.ac.id*, afninelvi@sttind.ac.id
}

\begin{abstract}
ABSTRAK
Bukit Tui adalah bukit batu gamping (limestone) atau bukit kapur yang berjajar di selatan Kota Padang Panjang. Letaknya berada antara Kelurahan Rao-Rao hingga Tanah Hitam. Kawasan Bukit Tui dengan luas area pertambangan lokal (APL) $\pm 329 \mathrm{Ha}$ dan sumber daya batu gamping sejumlah 6.144.663.609 ton $(\rho=2,4$ ton/ $\mathrm{m}^{3}$ ). Penambangan batu gamping atau batu kapur di Kawasan Bukit Tui masih dilakukan secara tradisional dengan skala kecil begitu juga pemanfaatannya, saat ini batu kapur hanya digunakan untuk kapur tohor dan tambak udang. Tujuan penelitian ini adalah untuk menganalisis kandungan unsur dan mineral dari batu gamping di Bukit Tui guna memenuhi requirement industri serta untuk membuat peta penyebaran kualitas batu gamping di Bukit Tui Kota Padang Panjang. Metode penelitian dilakukan dengan pengumpulan data primer berupa koordinat pengambilan sampel dan Sampel batu gamping. Sampel batu gamping diambil dari 8 titik koordinat. Sampel batu gamping yang telah diambil kemudian diamati sifat fisika dan kimianya. Sifat fisika dan kimia dari batugamping diperoleh dengan cara melakukan uji XRF dan uji XRD. Dari hasil XRF, batu gamping Bukit Tui menunjukkan termasuk jenis kalsium dengan kemurnian tinggi yang tersusun dari unsur $\mathrm{Ca}(97,92 \%)$, unsur $\mathrm{Ag}$ $(0,7 \%)$, unsur $\mathrm{Al}(0,3 \%)$ dan $\mathrm{Si}(0,1 \%)$ sedangkan hasil XRD menunjukkan batu gamping Bukit Tui didominasi oleh senyawa $\mathrm{CaO}(97,34 \%), \mathrm{P}_{2} \mathrm{O}_{5}(0,95 \%), \mathrm{Ag}_{2} \mathrm{O}(0,627 \%)$ dan $\mathrm{Al}_{2} \mathrm{O}_{3}(0,504 \%)$. Dari hasil XRD dan standar penggunaan batu kapur menurut beberapa requirement industri maka batu gamping Bukit Tui bisa dimanfaatkan untuk industri baja, industri kaca, industri semen, industri gula, bata silika dan kokas.
\end{abstract}

Kata kunci: XRF, XRD, Batugamping, Bukit tui, Padang Panjang

\begin{abstract}
Bukit Tui is a limestone hill that lines the south of Padang Panjang City. It is located between Rao-Rao Village and Tanah Hitam. Bukit Tui area with a local mining area (APL) of $\pm 329 \mathrm{Ha}$ and limestone resources of 6,144,663,609 tons $(\rho=2.4$ tons/m3). Limestone mining in the Bukit Tui area is still done traditionally on a small scale as well as its utilization, currently limestone is only used for quicklime and shrimp ponds. The purpose of this study was to analyze the elemental and mineral content of limestone in Bukit Tui in order to meet industrial requirements and to create a distribution map of the quality of limestone in Bukit Tui, Padang Panjang City. The research method was carried out by collecting primary data in the form of coordinates for sampling and limestone samples. Limestone samples were taken from 8 coordinate points. Limestone samples that have been taken are then observed for their physical and chemical properties. Physical and chemical properties of limestone were obtained by conducting XRF and XRD tests. From the XRF results, the limestone of Bukit Tui shows that it is a type of high purity calcium composed of Ca (97.92\%), Ag (0.7\%), Al (0.3\%) and $\mathrm{Si}(0.1)$. \%) while XRD results show that Bukit Tui limestone is dominated by CaO (97.34\%), P2O5 (0.95\%), Ag2O (0.627\%) and Al2O3 (0.504\%). From its elements and compounds, Bukit Tui limestone can be used for the steel industry, glass industry, cement industry, sugar industry, silica brick and coke.
\end{abstract}

Keywords: XRF, XRD, limestone, Bukit Tui, Padang Panjang

diunggah: September 2021, direvisi: November 2021, diterima: Desember 2021, dipublikasi: Desember 2021

Copyright (c) 2021 Riam Marlina A, Afni Nelvi

This is an open access article under the CC-BY license 


\section{PENDAHULUAN}

Kawasan Bukit Tui Kota Padang Panjang berada sebelah utara Bukit Jarat dengan luas $\pm 865 \mathrm{Ha}$, terdiri dari kawasan hutan lindung $\pm 536 \mathrm{Ha}$ dan area pertambangan lokal (APL) \pm 329 Ha. Untuk wilayah administrasi Kota Padang Panjang, sebaran batu gamping ini berada di bukit barisan yang berbatasan dengan wilayah Kabupaten Tanah Datar dan sebagian Padang Pariaman. Sebaran sumberdaya batu gamping pada wilayah administrasi Kota Padang Panjang dapat dilihat pada Gambar 1 dibawah ini. Dari hasil perhitungan dengan metode garis kontur pada daerah batasan perhitungan sumberdaya seluas $818 \mathrm{Ha}$, maka didapatkan sumberdaya batu gamping sejumlah 6.144 .663 .609 ton $\left(\rho=2,4 \mathrm{ton} / \mathrm{m}^{3}\right)$. Sumberdaya ini ditutupi oleh tanah penutup dengan volume $10.298 .870 \mathrm{~m}^{3}$. Perhitungan dilakukan dengan membuat garis kontur dengan interval $25 \mathrm{~m}$ pada batas perhitungan elevasi $700-1375 \mathrm{~m}$. Secara Administratif sebaran sumberdaya ini berada pada dua daerah, yaitu: Kota Padang Panjang dan Kabupaten Tanah Datar (ESDM, 2015).

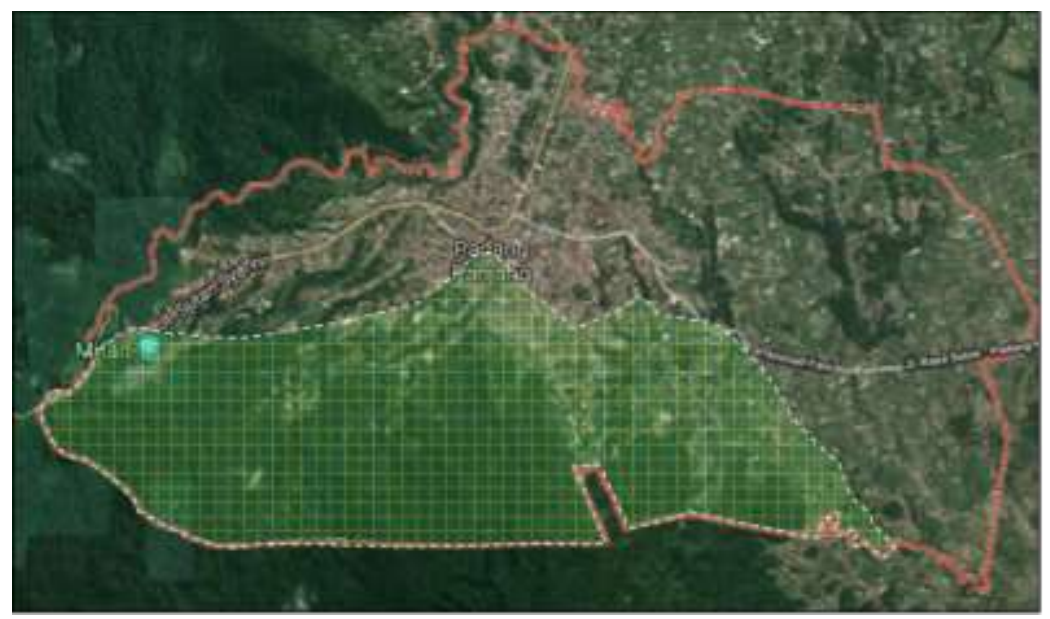

Gambar 1. Sebaran sumberdaya batu gamping kota padang panjang (Sumber: BP3D Kota Padang Panjang, 2019)

Meskipun memiliki sumberdaya yang besar, tetapi penambangan batu gamping di Kawasan Bukit Tui masih dilakukan secara tradisional dengan skala kecil. Untuk pemasaran, para pelaku usaha industri batu kapur di Kawasan Bukit Tui belum memiliki target pemasaran yang pasti dan produk yang dipasarkan hanya berupa kapur tohor dan kalsium karbonat giling. Kapur tohor digunakan sebagai perekat dalam adukan semen, pemutih pada tembok dan tambak udang. Pelaku usaha industri batu kapur hanya bergantung kepada konsumen yang memesan tanpa ada kontrak atau ikatan apapun sehingga masih bernilai ekonomis rendah. Hal ini dikarenakan pelaku industri tidak mengetahui kualitas batu gamping yang sesuai dengan requirement Industri. Padahal masih banyak kegunaan dari campuran batu gamping dalam requirement industri besar, tentu dengan mengetahui karakteristik unsur dan senyawa batu gamping tersebut, industri yang juga memanfaatkan batu gamping adalah industri manufaktur baja, metalurgi, industri gula, industri kertas, industri karet, industri semen dengan standar yang ditetapkan.

Penelitian ini dilakukan untuk memberikan gambaran pada pelaku industri tentang kualitas batu kapur sesuai dengan requirement industri serta pemetaan kualitas batu gamping. Informasi mengenai kandungan unsur yang terkandung dalam batugamping, dapat diperoleh dengan menggunakan karakterisasi X-Ray Fluorescence (XRF) sedangkan kualitas batu gamping serta karakterisasi dan mineral yang terkandung dalam batugamping diperoleh dengan menggunakan X-Ray Diffraction (XRD). XRF merupakan salah satu instrumen yang umumnya digunakan sebagai uji pendahuluan suatu material untuk mengetahui kandungan 
mineral, karena tidak merusak sampel yang dianalisis, tidak membutuhkan standar, dan akurasi yang relatif tinggi. Sementara kemurnian suatu senyawa dapat diperoleh dari hasil analisis menggunakan XRD, berupa pola puncak difraktogram yang khas dengan intesitas tertentu (Munasir, dkk, 2021). Data yang diperoleh dari hasil analisis XRF dan XRD dapat digunakan sebagai bahan pertimbangan dalam pemanfaatan batugamping untuk industri.

Batu gamping (batu kapur) atau limestone sering terbentuk di perairan laut dangkal. Batu gamping kebanyakan merupakan batuan sedimen organik yang terbentuk dari akumulasi cangkang, karang, alga, dan pecahan-pecahan sisa organisme. Batu gamping juga dapat menjadi batuan sedimen kimia yang terbentuk oleh pengendapan kalsium karbonat dari air danau ataupun air laut. Pada industri semen, fondasi jalan dan rumah batu kapur bisa langsung digunakan, sedangkan untuk produk industri diperlukan pengolahan terlebih dahulu misalnya dengan pembakaran. Cara ini dimaksudkan untuk memperoleh kapur tohor $(\mathrm{CaO})$, kalsium hidroksida $\left(\mathrm{Ca}(\mathrm{OH})_{2}\right)$ dan gas $\mathrm{CO}$. Dalam peleburan dan pemurnian besi atau logam lainnya, batu gamping/dolomit berfungsi sebagai imbuh pada tanur tinggi. Bijih besi mengandung silika dan alumina sebagai unsur tambahan serta dalam proses peleburan unsurunsur tersebut bersenyawa dengan bahan pengimbuh berupa terak cair (seng) yang mengapung di atas lelehan besi, sehingga mudah dipisahkan. Disamping itu, $\mathrm{CaO}$ dalam batu gamping harus berkadar tinggi, hal itu diperlukan untuk mengikat gas-gas seperti $\mathrm{SO}_{2}$ dan $\mathrm{H}_{2} \mathrm{~S}$. Gambar 2 dibawah ini merupakan pemanfaatan umum batu kapur dan proses pengolahan serta jenis yang dibutuhkan dalam requirement industri (Garinas, 2019).

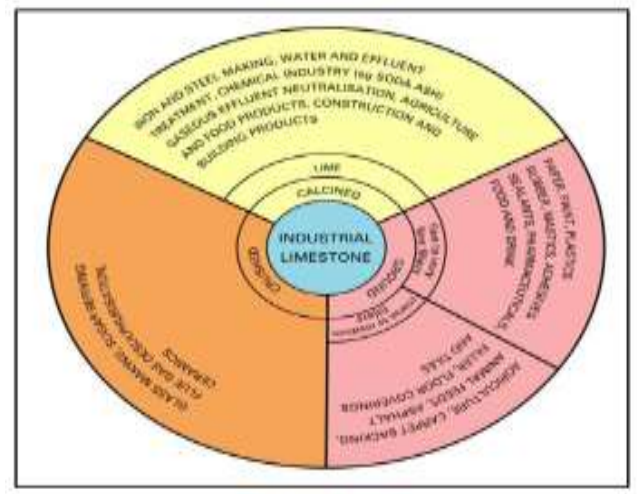

Gambar 2. Pemanfaatan batu kapur dalam requirement industri

(Sumber: BGS dalam Garinas, 2019)

Tujuan Penelitian ini adalah menganalisis kandungan unsur dan mineral batu gamping di Kawasan Bukit Tui untuk memenuhi requirement industri dan membuat peta penyebaran kualitas batu gamping di Kawasan Bukit Tui. Pemanfaatan batu kapur pada sektor industri harus memenuhi standar tertentu. Kemurnian batu kapur menurut Standar British Geological Survey (BGS) dapat dilihat pada Tabel 1 di bawah ini.

Tabel 1. Kemurnian batu kapur menurut standar british geological survey (BGS)

\begin{tabular}{|l|c|c|c|c|c|}
\hline $\begin{array}{c}\text { Limestone } \\
\text { classification }\end{array}$ & $\begin{array}{c}\mathrm{CaO} \\
(\mathrm{wt} \%)\end{array}$ & $\begin{array}{c}\mathrm{CaCO}_{3} \\
(\mathrm{wt} \%)\end{array}$ & $\begin{array}{c}\mathrm{MgO} \\
(\mathrm{wt} \%)\end{array}$ & $\begin{array}{c}\mathrm{SIO}_{2} \\
(\text { wt \%) }\end{array}$ & $\begin{array}{c}\mathrm{Fe}_{2} \mathrm{O}_{3} \\
\text { (wt \%) }\end{array}$ \\
\hline 100\% limestone & 56.03 & 100.0 & & & \\
\hline Very high purity & $>55.2$ & $>98.5$ & $<0.8$ & $<0.2$ & $<0.05$ \\
\hline High purity & $54.3-55.2$ & $97.0-98.5$ & $<1.0$ & $<0.6$ & $<0.1$ \\
\hline Medium purity & $52.4-54.3$ & $93.5-97.0$ & $<3.0$ & $<1.0$ & $<1.0$ \\
\hline Low purity & $47.6-52.4$ & $85.0-93.5$ & $>3.0$ & $<2.0$ & $>0.1$ \\
\hline
\end{tabular}

(Sumber: Garinas, 2019)

Sedangkan standar penggunaan batu kapur menurut beberapa requirement industri dari berbagai sumber dapat dilihat pada Tabel 2 di bawah ini. 
Tabel 2. Standar kualitas batu kapur menurut requirement industri

\begin{tabular}{|c|l|c|c|c|l|l|l|}
\hline \multirow{2}{*}{ No } & \multirow{2}{*}{ Parameter } & \multicolumn{7}{|c|}{ Kadar (\%) } \\
\cline { 3 - 8 } & $\begin{array}{l}\text { Industri } \\
\text { Baja }\end{array}$ & $\begin{array}{l}\text { Industri } \\
\text { Kaca }\end{array}$ & $\begin{array}{l}\text { Industri } \\
\text { Semen }\end{array}$ & $\begin{array}{l}\text { Industri } \\
\text { Gula }\end{array}$ & $\begin{array}{l}\text { Bata } \\
\text { Silika }\end{array}$ & Karbit \\
\hline 1 & $\mathrm{CaO}$ & $>51.0$ & 55.8 & $50-55$ & 55 & 90 & 92 \\
\hline 2 & $\mathrm{SiO}_{2}$ & $<1.2$ & 0.96 & - & 0.1 & - & 2 \\
\hline 3 & $\mathrm{Al}_{2} \mathrm{O}_{3}$ & $<0.9$ & 0.14 & 0.95 & 0.1 & - & 1 \\
\hline 4 & $\mathrm{MgO}_{5}$ & - & 0.15 & 2 & 0.4 & 4.5 & 1.75 \\
\hline 6 & $\mathrm{Fe}_{2} \mathrm{O}_{3}$ & - & 0.04 & 2.47 & - & 1.5 & 1 \\
\hline 7 & $\mathrm{CO}_{2}$ & - & - & - & - & - & 0.02 \\
\hline 8 & $\mathrm{Kadar}_{4}$ Air & - & - & - & - & 55.8 & - \\
\hline
\end{tabular}

\section{METODE}

Jenis penelitian pada penelitian ini adaah penelitian kuantitatif. Pengumpulan data pada penelitian ini dimulai dengan melakukan pengambilan sampel primer batu gamping di beberapa titik di wilayah Bukit Tui Kota Padang Panjang. Sampel yang diambil sebanyak 8 titik dengan lokasi Rao-rao, Koto Panjang, Tanah Hitam, Kampung Manggis dan Sungai Andok. Nama titik dan koordinat pengambilan sampel ditampilkan pada Tabel 3 berikut.

Tabel 3 Nama dan koordinat titik sampel

\begin{tabular}{|c|rrr|rrr|}
\hline No. & \multicolumn{3}{|c|}{ Bujur Timur } & \multicolumn{3}{|c|}{ Lintang Selatan } \\
\hline SRM 01 & $100^{\circ}$ & $21^{\prime}$ & $17.05^{\prime \prime}$ & $0^{\circ}$ & $28^{\prime}$ & $41.7^{\prime \prime}$ \\
SRM 02 & $100^{\circ}$ & $24^{\prime}$ & $19.84^{\prime \prime}$ & $0^{\circ}$ & $28^{\prime}$ & $48.21^{\prime \prime}$ \\
SRM 03 & $100^{\circ}$ & $24^{\prime}$ & $21.06^{\prime \prime}$ & $0^{\circ}$ & $28^{\prime}$ & $42.9^{\prime \prime}$ \\
SRM 04 & $100^{\circ}$ & $23^{\prime}$ & $2.34^{\prime \prime}$ & $0^{\circ}$ & $28^{\prime}$ & $36.20^{\prime \prime}$ \\
SRM 05 & $100^{\circ}$ & $23^{\prime}$ & $26.44^{\prime \prime}$ & $0^{\circ}$ & $28^{\prime}$ & $28,12^{\prime \prime}$ \\
SRM 06 & $100^{\circ}$ & $24^{\prime}$ & $2.70^{\prime \prime}$ & $0^{\circ}$ & $28^{\prime}$ & $19.07^{\prime \prime}$ \\
SRM 07 & $100^{\circ}$ & $24^{\prime}$ & $5.49^{\prime \prime}$ & $0^{\circ}$ & $28^{\prime}$ & $22.97^{\prime \prime}$ \\
SRM 08 & $100^{\circ}$ & $24^{\prime}$ & $8.50^{\prime \prime}$ & $0^{\circ}$ & $28^{\prime}$ & $24.40^{\prime \prime}$ \\
\hline
\end{tabular}

Kemudian penanganan sampel batu gamping dilakukan dengan prosedur seperti pada Gambar 3 dibawah ini.

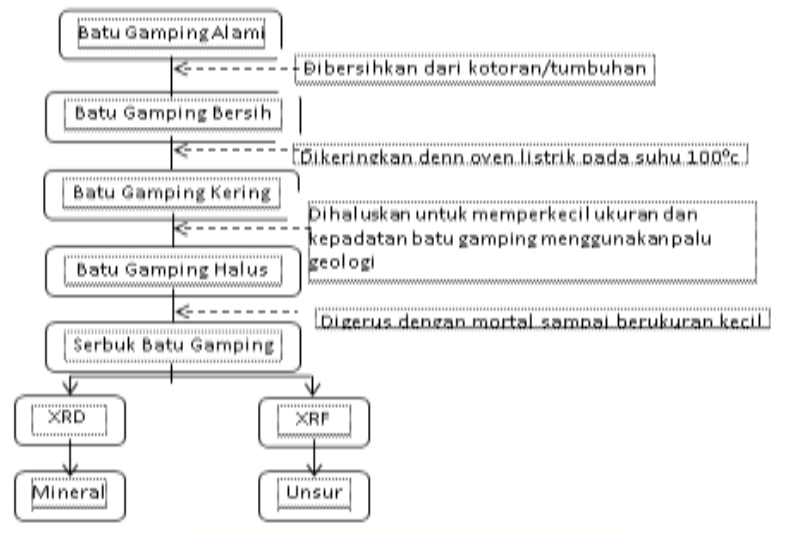

Gambar 3. Prosedur eksperimen XRF dan XRD

Preparasi sampel Batu Gamping dilakukan di Laboratorium Tambang Universitas Negeri Padang untuk dilakukan proses pemilahan, penghalusan dan penggerusan menggunakan mortal, jawcrusher dan grinder hingga menjadi bubuk batu gamping dengan ukuran $250 \mu \mathrm{m}$ yang siap diuji dengan instrumen XRD dan XRF. Kegiatan penyiapan sampel 
batuan (preparasi sampel) dapat dilihat pada Gambar 4 dibawah ini. Sedangkan Uji X-Ray Fluorescence (XRF) dilakukan di laboratorium Fisika dan X- Ray Diffraction (XRD) dilakukan di Laboratorium Penelitian Kimia Fakultas Matematika dan Ilmu Pengetahuan Alam Universitas Negeri Padang.

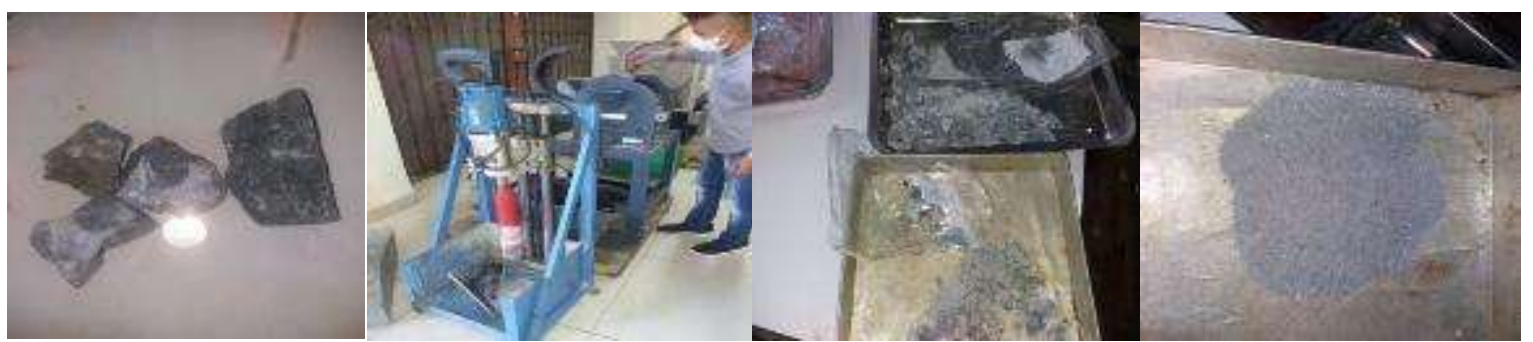

Gambar 4. Preparasi sampel batu gamping

Analisa data dilakukan setelah hasil senyawa yang didapat dari metode XRD didapat kemudian dianalisis dengan menggunakan standar penggunaan batu kapur menurut beberapa requirement industri, sedangkan unsur yang didapat dari XRF digunakan untuk pembuatan peta penyebaran batu gamping di Bukit Tui.

Gambaran kemuktahiran penelitian ini dapat dilihat pada gambar 5 dibawah ini.
Lingkup Penelitian
Bidang di Teliti
Kemutakhiran

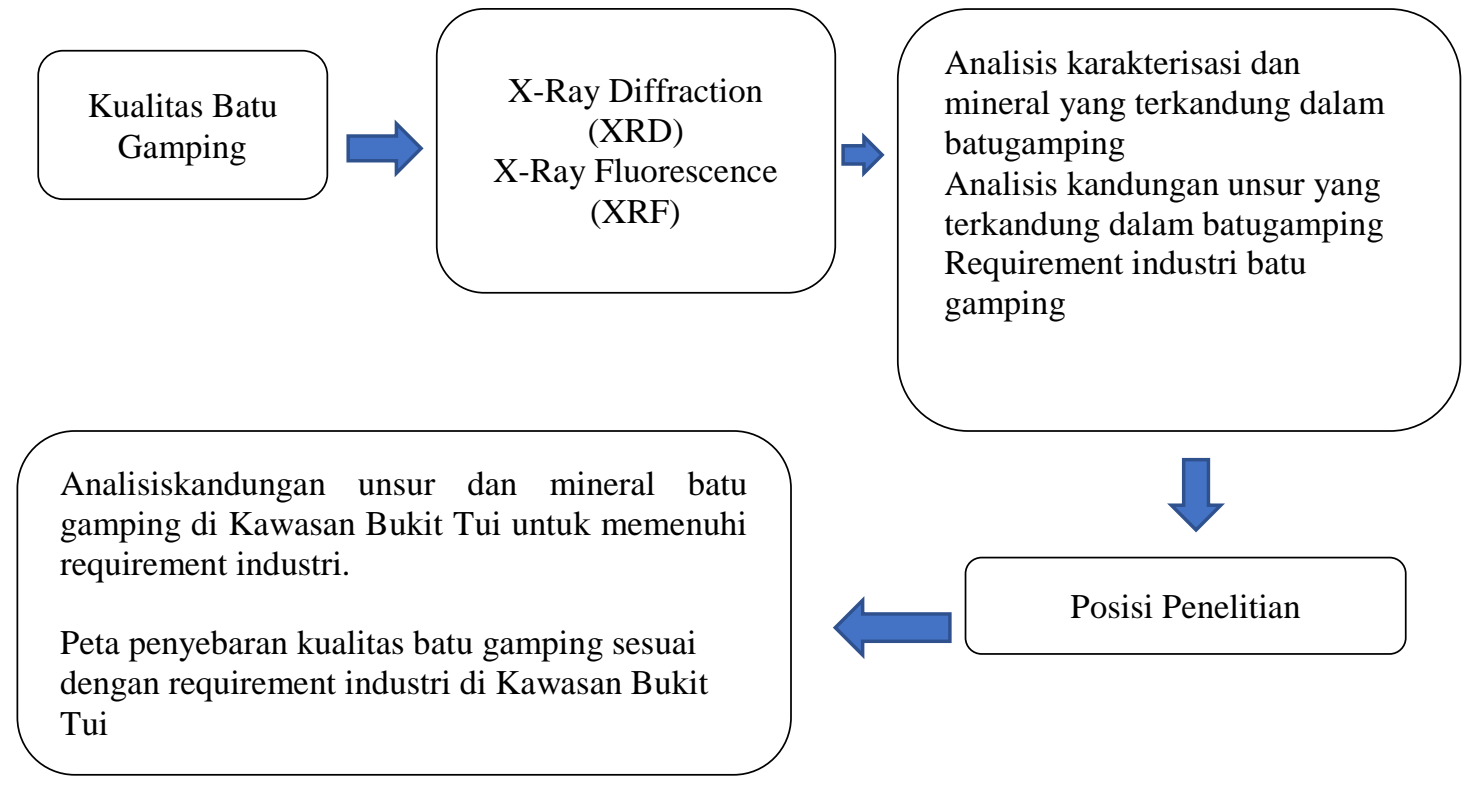

Gambar 5. Bagan alir penelitian

\section{HASIL DAN PEMBAHASAN}

Kandungan unsur dari sampel Batu Gamping Bukit Tui dari pengujian instrumen XRF memperlihatkan dominan unsur Kalsium (Ca) sebanyak 97,92\%, kemudian diikuti unsur perak (Ag) sebanyak 0,7\%, Aluminium (Al) sebanyak 0,3\% dan Silikon (Si) sebanyak 0,1\% seperti di sajikan pada Tabel 4 dibawah ini. 
Tabel 4. Komposisi unsur batu gamping bukit tui

\begin{tabular}{|c|c|c|c|c|c|c|c|c|c|c|c|c|c|c|c|c|}
\hline \multirow{2}{*}{ No } & \multicolumn{2}{|c|}{ SRM 01} & \multicolumn{2}{|c|}{ SRM 02} & \multicolumn{2}{|c|}{ SRM 03} & \multicolumn{2}{|c|}{ SRM 04} & \multicolumn{2}{|c|}{ SRM 05 } & \multicolumn{2}{|c|}{ SRM 06} & \multicolumn{2}{|c|}{ SRM 07} & \multicolumn{2}{|c|}{ SRM 08} \\
\hline & Unsur & $\%$ & Unsur & $\%$ & Unsur & $\%$ & Unsur & $\%$ & Unsur & $\%$ & Unsur & $\%$ & Unsur & $\%$ & Unsur & $\%$ \\
\hline 1 & $\mathrm{Al}$ & 0,311 & $\mathrm{Al}$ & 0,311 & $\mathrm{Al}$ & 0,433 & $\mathrm{Al}$ & 0,599 & $\mathrm{Al}$ & 0,599 & $\mathrm{Al}$ & 0,311 & $\mathrm{Al}$ & 0,311 & $\mathrm{Al}$ & 0,311 \\
\hline 2 & $\mathrm{Si}$ & 0,137 & $\mathrm{Si}$ & 0,137 & $\mathrm{Si}$ & 0,323 & $\mathrm{Si}$ & 0,713 & $\mathrm{Si}$ & 0,713 & $\mathrm{Si}$ & 0,137 & $\mathrm{Si}$ & 0,137 & $\mathrm{Si}$ & 0,137 \\
\hline 3 & $\mathrm{P}$ & 0,47 & $\mathrm{P}$ & 0,47 & $\mathrm{P}$ & 0,469 & $\mathrm{P}$ & 0,509 & $\mathrm{P}$ & 0,509 & $\mathrm{P}$ & 0,47 & $\mathrm{P}$ & 0,47 & $\mathrm{P}$ & 0,47 \\
\hline 4 & $\mathrm{Cl}$ & 0 & $\mathrm{Cl}$ & 0 & $\mathrm{Cl}$ & 0,017 & $\mathrm{Cl}$ & 0,001 & $\mathrm{Cl}$ & 0,001 & $\mathrm{Cl}$ & 0 & $\mathrm{Cl}$ & 0 & $\mathrm{Cl}$ & 0 \\
\hline 5 & $\mathrm{Ca}$ & 97,92 & $\mathrm{Ca}$ & 97,92 & $\mathrm{~K}$ & 0 & $\mathrm{Ca}$ & 97,1 & $\mathrm{Ca}$ & 97,1 & $\mathrm{Ca}$ & 97,92 & $\mathrm{Ca}$ & 97,92 & $\mathrm{Ca}$ & 97,92 \\
\hline 6 & $\mathrm{Ti}$ & 0,005 & $\mathrm{Ti}$ & 0,005 & $\mathrm{Ca}$ & 97,04 & $\mathrm{Ti}$ & 0,02 & $\mathrm{Ti}$ & 0,02 & $\mathrm{Ti}$ & 0,005 & $\mathrm{Ti}$ & 0,005 & $\mathrm{Ti}$ & 0,005 \\
\hline 7 & $\mathrm{Mn}$ & 0,003 & $\mathrm{Mn}$ & 0,003 & $\mathrm{Ti}$ & 0,026 & $\mathrm{~V}$ & 0,006 & $\mathrm{~V}$ & 0,006 & $\mathrm{Mn}$ & 0,003 & $\mathrm{Mn}$ & 0,003 & $\mathrm{Mn}$ & 0,003 \\
\hline 8 & $\mathrm{Fe}$ & 0,18 & $\mathrm{Fe}$ & 0,18 & $\mathrm{~V}$ & 0,002 & $\mathrm{Mn}$ & 0,004 & $\mathrm{Mn}$ & 0,004 & $\mathrm{Fe}$ & 0,18 & $\mathrm{Fe}$ & 0,18 & $\mathrm{Fe}$ & 0,18 \\
\hline 9 & $\mathrm{Zn}$ & 0,011 & $\mathrm{Zn}$ & 0,011 & $\mathrm{Mn}$ & 0,007 & $\mathrm{Fe}$ & 0,147 & $\mathrm{Fe}$ & 0,147 & $\mathrm{Zn}$ & 0,011 & $\mathrm{Zn}$ & 0,011 & $\mathrm{Zn}$ & 0,011 \\
\hline 10 & $\mathrm{Sr}$ & 0,071 & $\mathrm{Sr}$ & 0,071 & $\mathrm{Fe}$ & 0,263 & $\mathrm{Zn}$ & 0,007 & $\mathrm{Zn}$ & 0,007 & $\mathrm{Sr}$ & 0,071 & $\mathrm{Sr}$ & 0,071 & $\mathrm{Sr}$ & 0,071 \\
\hline 11 & $\mathrm{Zr}$ & 0,002 & $\mathrm{Zr}$ & 0,002 & $\mathrm{Zn}$ & 0,04 & $\mathrm{Sr}$ & 0,119 & $\mathrm{Sr}$ & 0,119 & $\mathrm{Zr}$ & 0,002 & $\mathrm{Zr}$ & 0,002 & $\mathrm{Zr}$ & 0,002 \\
\hline 12 & $\mathrm{Ag}$ & 0,794 & $\mathrm{Ag}$ & 0,794 & $\mathrm{Sr}$ & 0,073 & $\mathrm{Zr}$ & 0,002 & $\mathrm{Zr}$ & 0,002 & $\mathrm{Ag}$ & 0,794 & $\mathrm{Ag}$ & 0,794 & $\mathrm{Ag}$ & 0,794 \\
\hline 13 & $\mathrm{Cd}$ & 0,068 & $\mathrm{Cd}$ & 0,068 & $\mathrm{Zr}$ & 0,002 & $\mathrm{Ag}$ & 0,667 & $\mathrm{Ag}$ & 0,667 & $\mathrm{Cd}$ & 0,068 & $\mathrm{Cd}$ & 0,068 & $\mathrm{Cd}$ & 0,068 \\
\hline 14 & $\mathrm{Ba}$ & 0,023 & $\mathrm{Ba}$ & 0,023 & $\mathrm{Ag}$ & 0,55 & $\mathrm{Cd}$ & 0,108 & $\mathrm{Cd}$ & 0,108 & $\mathrm{Ba}$ & 0,023 & $\mathrm{Ba}$ & 0,023 & $\mathrm{Ba}$ & 0,023 \\
\hline 15 & $\mathrm{Sm}$ & 0 & $\mathrm{Sm}$ & 0 & $\mathrm{Cd}$ & 0 & $\mathrm{Nd}$ & 0 & $\mathrm{Nd}$ & 0 & $\mathrm{Sm}$ & 0 & $\mathrm{Sm}$ & 0 & $\mathrm{Sm}$ & 0 \\
\hline 16 & $\mathrm{Re}$ & 0,001 & $\mathrm{Re}$ & 0,001 & In & 0,708 & $\mathrm{Sm}$ & 0 & $\mathrm{Sm}$ & 0 & $\mathrm{Re}$ & 0,001 & $\mathrm{Re}$ & 0,001 & $\mathrm{Re}$ & 0,001 \\
\hline 17 & & & & & $\mathrm{Ba}$ & 0,013 & $\mathrm{Eu}$ & 0 & $\mathrm{Eu}$ & 0 & & & & & & \\
\hline 18 & & & & & $\mathrm{Sm}$ & 0 & $\mathrm{Re}$ & 0 & $\mathrm{Re}$ & 0 & & & & & & \\
\hline 19 & & & & & $\mathrm{Eu}$ & 0 & & & & & & & & & & \\
\hline 20 & & & & & $\mathrm{Lu}$ & 0,037 & & & & & & & & & & \\
\hline 21 & & & & & $\mathrm{Re}$ & 0 & & & & & & & & & & \\
\hline
\end{tabular}

Sedangkan senyawa yang terkandung pada Batu Gamping Bukit Tui terbanyak kalsium oksida $(\mathrm{CaO})$ sebanyak 97,34\%, difosfor pentoksida $\left(\mathrm{P}_{2} \mathrm{O}_{5}\right)$ sebanyak 0,95\%, Perak oksida $\left(\mathrm{Ag}_{2} \mathrm{O}\right)$ sebanyak $0,627 \%$ dan Aluminium oksida $\left(\mathrm{Al}_{2} \mathrm{O}_{3}\right)$ sebanyak $0,504 \%$ untuk lebih rinci dapat dilihat pada tabel 5 . 
Tabel 5. Komposisi senyawa batu gamping bukit tui

\begin{tabular}{|c|c|c|c|c|c|c|c|c|c|c|c|c|c|c|c|c|}
\hline \multirow{2}{*}{ No } & \multicolumn{2}{|c|}{ SRM 01} & \multicolumn{2}{|c|}{ SRM 02} & \multicolumn{2}{|c|}{ SRM 03} & \multicolumn{2}{|c|}{ SRM 04} & \multicolumn{2}{|c|}{ SRM 05} & \multicolumn{2}{|c|}{ SRM 06} & \multicolumn{2}{|c|}{ SRM 07} & \multicolumn{2}{|c|}{ SRM 08} \\
\hline & \begin{tabular}{|l|} 
Senyawaa \\
\end{tabular} & $\%$ & \begin{tabular}{|l|} 
Senyawa \\
\end{tabular} & $\%$ & \begin{tabular}{|l|l|} 
Senyawa \\
\end{tabular} & $\%$ & \begin{tabular}{|l|l|} 
Senyawa \\
\end{tabular} & $\%$ & Senyawa & $\%$ & Senyawa & $\%$ & Senyawa & $\%$ & \begin{tabular}{|l|l|} 
Senyawa \\
\end{tabular} & $\%$ \\
\hline 1 & $\mathrm{Al} 2 \mathrm{O} 3$ & 0,504 & $\mathrm{Al} 2 \mathrm{O} 3$ & 0,504 & $\mathrm{Al} 2 \mathrm{O} 3$ & 0,698 & $\mathrm{~A} 12 \mathrm{O} 3$ & 0,971 & $\mathrm{Al} 2 \mathrm{O} 3$ & 0,971 & $\mathrm{Al} 2 \mathrm{O} 3$ & 0,504 & $\mathrm{Al} 2 \mathrm{O} 3$ & 0,504 & $\mathrm{Al} 2 \mathrm{O} 3$ & 0,504 \\
\hline 2 & $\mathrm{SiO} 2$ & 0,25 & $\mathrm{SiO} 2$ & 0,25 & $\mathrm{SiO} 2$ & 0,587 & $\mathrm{SiO} 2$ & 1,301 & $\mathrm{SiO} 2$ & 1,301 & $\mathrm{SiO} 2$ & 0,25 & $\mathrm{SiO} 2$ & 0,25 & $\mathrm{SiO} 2$ & 0,25 \\
\hline 3 & $\mathrm{P} 2 \mathrm{O} 5$ & 0,915 & $\mathrm{P} 2 \mathrm{O} 5$ & 0,915 & $\mathrm{P} 2 \mathrm{O} 5$ & 0,905 & $\mathrm{P} 2 \mathrm{O} 5$ & 0,977 & $\mathrm{P} 2 \mathrm{O} 5$ & 0,977 & $\mathrm{P} 2 \mathrm{O} 5$ & 0,915 & $\mathrm{P} 2 \mathrm{O} 5$ & 0,915 & $\mathrm{P} 2 \mathrm{O} 5$ & 0,915 \\
\hline 4 & $\mathrm{CaO}$ & 97,34 & $\mathrm{CaO}$ & 97,34 & $\mathrm{~K} 2 \mathrm{O}$ & 0 & $\mathrm{CaO}$ & 95,84 & $\mathrm{CaO}$ & 95,84 & $\mathrm{CaO}$ & 97,34 & $\mathrm{CaO}$ & 97,34 & $\mathrm{CaO}$ & 97,34 \\
\hline 5 & TiO2 & 0,006 & TiO2 & 0,006 & $\mathrm{CaO}$ & 96,3 & $\mathrm{TiO} 2$ & 0,022 & $\mathrm{TiO} 2$ & 0,022 & TiO2 & 0,006 & $\mathrm{TiO} 2$ & 0,006 & $\mathrm{TiO} 2$ & 0,006 \\
\hline 6 & $\mathrm{MnO}$ & 0,002 & $\mathrm{MnO}$ & 0,002 & $\mathrm{TiO} 2$ & 0,029 & V2O5 & 0,007 & V2O5 & 0,007 & $\mathrm{MnO}$ & 0,002 & $\mathrm{MnO}$ & 0,002 & $\mathrm{MnO}$ & 0,002 \\
\hline 7 & $\mathrm{Fe} 2 \mathrm{O} 3$ & 0,167 & $\mathrm{Fe} 2 \mathrm{O} 3$ & 0,167 & $\mathrm{~V} 2 \mathrm{O} 5$ & 0,002 & $\mathrm{MnO}$ & 0,003 & $\mathrm{MnO}$ & 0,003 & $\mathrm{Fe} 2 \mathrm{O} 3$ & 0,167 & $\mathrm{Fe} 2 \mathrm{O} 3$ & 0,167 & $\mathrm{Fe} 2 \mathrm{O} 3$ & 0,167 \\
\hline 8 & $\mathrm{ZnO}$ & 0,009 & $\mathrm{ZnO}$ & 0,009 & $\mathrm{MnO}$ & 0,006 & $\mathrm{Fe} 2 \mathrm{O} 3$ & 0,135 & $\mathrm{Fe} 2 \mathrm{O} 3$ & 0,135 & $\mathrm{ZnO}$ & 0,009 & $\mathrm{ZnO}$ & 0,009 & $\mathrm{ZnO}$ & 0,009 \\
\hline 9 & $\mathrm{SrO}$ & 0,055 & $\mathrm{SrO}$ & 0,055 & $\mathrm{Fe} 2 \mathrm{O} 3$ & 0,244 & $\mathrm{ZnO}$ & 0,006 & $\mathrm{ZnO}$ & 0,006 & $\mathrm{SrO}$ & 0,055 & $\mathrm{SrO}$ & 0,055 & $\mathrm{SrO}$ & 0,055 \\
\hline 10 & $\mathrm{ZrO} 2$ & 0,001 & $\mathrm{ZrO} 2$ & 0,001 & $\mathrm{ZnO}$ & 0,033 & $\mathrm{SrO}$ & 0,09 & $\mathrm{SrO}$ & 0,09 & $\mathrm{ZrO} 2$ & 0,001 & $\mathrm{ZrO} 2$ & 0,001 & $\mathrm{ZrO} 2$ & 0,001 \\
\hline 11 & $\mathrm{Ag} 2 \mathrm{O}$ & 0,677 & $\mathrm{Ag} 2 \mathrm{O}$ & 0,677 & $\mathrm{SrO}$ & 0,056 & $\mathrm{ZrO} 2$ & 0,002 & $\mathrm{ZrO} 2$ & 0,002 & $\mathrm{Ag} 2 \mathrm{O}$ & 0,677 & $\mathrm{Ag} 2 \mathrm{O}$ & 0,677 & $\mathrm{Ag} 2 \mathrm{O}$ & 0,677 \\
\hline 12 & $\mathrm{CdO}$ & 0,055 & $\mathrm{CdO}$ & 0,055 & $\mathrm{ZrO} 2$ & 0,002 & $\mathrm{Ag} 2 \mathrm{O}$ & 0,54 & $\mathrm{Ag} 2 \mathrm{O}$ & 0,54 & $\mathrm{CdO}$ & 0,055 & $\mathrm{CdO}$ & 0,055 & $\mathrm{CdO}$ & 0,055 \\
\hline 13 & $\mathrm{BaO}$ & 0,016 & $\mathrm{BaO}$ & 0,016 & $\mathrm{Ag} 2 \mathrm{O}$ & 0,46 & $\mathrm{CdO}$ & 0,105 & $\mathrm{CdO}$ & 0,105 & $\mathrm{BaO}$ & 0,016 & $\mathrm{BaO}$ & 0,016 & $\mathrm{BaO}$ & 0,016 \\
\hline 14 & $\mathrm{Sm} 2 \mathrm{O} 3$ & 0 & $\mathrm{Sm} 2 \mathrm{O} 3$ & 0 & $\mathrm{CdO}$ & 0 & $\mathrm{Nd} 2 \mathrm{O} 3$ & 0 & $\mathrm{Nd} 2 \mathrm{O} 3$ & 0 & $\mathrm{Sm} 2 \mathrm{O} 3$ & 0 & $\mathrm{Sm} 2 \mathrm{O} 3$ & 0 & $\mathrm{Sm} 2 \mathrm{O} 3$ & 0 \\
\hline 15 & $\mathrm{Cl}$ & 0 & $\mathrm{Cl}$ & 0 & In $2 \mathrm{O}_{3}$ & 0,626 & $\mathrm{Sm} 2 \mathrm{O} 3$ & 0 & $\mathrm{Sm} 2 \mathrm{O} 3$ & 0 & $\mathrm{Cl}$ & 0 & $\mathrm{Cl}$ & 0 & $\mathrm{Cl}$ & 0 \\
\hline 16 & $\operatorname{Re}$ & 0,001 & $\operatorname{Re}$ & 0,001 & $\mathrm{BaO}$ & 0,009 & $\mathrm{Eu} 2 \mathrm{O} 3$ & 0 & Eu2O3 & 0 & $\operatorname{Re}$ & 0,001 & $\operatorname{Re}$ & 0,001 & $\mathrm{Re}$ & 0,001 \\
\hline 17 & & & & & $\mathrm{Sm} 2 \mathrm{O} 3$ & 0 & $\mathrm{Cl}$ & 0,001 & $\mathrm{Cl}$ & 0,001 & & & & & & \\
\hline 18 & & & & & $\mathrm{Eu} 2 \mathrm{O} 3$ & 0 & $\operatorname{Re}$ & 0 & $\operatorname{Re}$ & 0 & & & & & & \\
\hline 19 & & & & & $\mathrm{Lu}_{2} \mathrm{O} 3$ & 0,025 & & & & & & & & & & \\
\hline 20 & & & & & $\mathrm{Cl}$ & 0,014 & & & & & & & & & & \\
\hline 21 & & & & & $\operatorname{Re}$ & 0 & & & & & & & & & & \\
\hline
\end{tabular}

Adapun hasil pengukuran XRD diperlihatkan pada Gambar 6, hasil analisis menunjukkan bahwa didominasi oleh satu unsur kristal yaitu kalsit atau senyawa kalsium karbonat $\left(\mathrm{CaCO}_{3}\right)$.

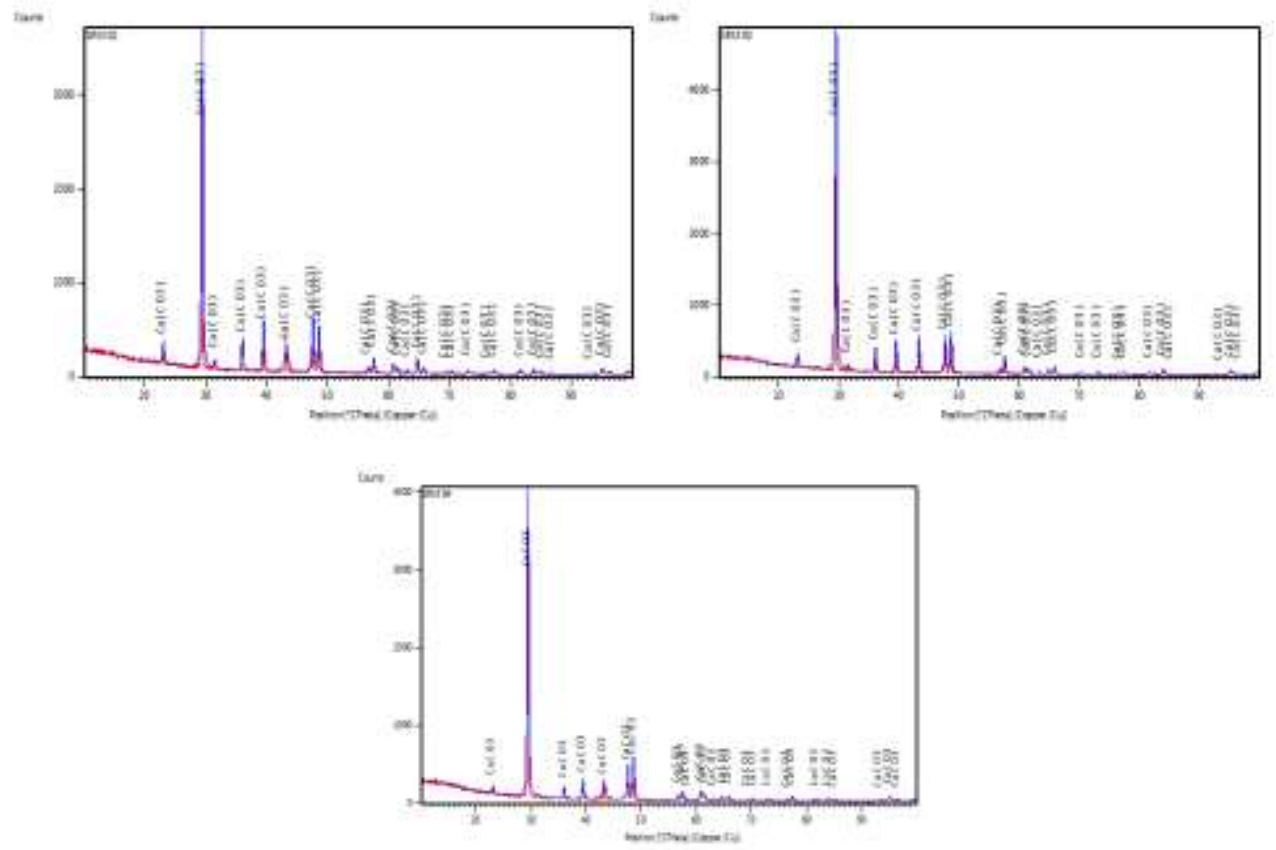

\section{Gambar 6. Sprektrum XRD dari sampel batu gamping}

Dari komposisi analisis XRF dan XRD maka batu gamping Bukit Tui dapat memenuhi syarat untuk dimanfaatkan untuk industri baja, industri kaca, industri semen, industri gula, bata silika dan kokas, seperti yang terlihat pada Tabel 6 di bawah ini. 
Tabel 6. Parameter pemanfaatan batu kapur bukit tui untuk requirement industri

\begin{tabular}{|c|c|c|c|c|c|c|c|c|c|c|c|c|c|c|}
\hline \multirow{3}{*}{$\begin{array}{c}\text { No } \\
1 \\
\end{array}$} & \multirow{3}{*}{$\begin{array}{l}\text { Parameter } \\
\mathrm{CaO}\end{array}$} & \multicolumn{13}{|c|}{ Kadar (\%) } \\
\hline & & \multirow{2}{*}{$\begin{array}{c}\text { Bukit } \\
\text { Tui } \\
97.4\end{array}$} & \multicolumn{2}{|c|}{ Ind.Baja } & \multicolumn{2}{|c|}{$\begin{array}{l}\text { Ind. } \\
\text { Kaca }\end{array}$} & \multicolumn{2}{|c|}{ Ind. Semen } & \multicolumn{2}{|c|}{$\begin{array}{l}\text { Ind. } \\
\text { Gula }\end{array}$} & \multicolumn{2}{|c|}{$\begin{array}{l}\text { Bata } \\
\text { Silika }\end{array}$} & \multicolumn{2}{|c|}{ Karbit } \\
\hline & & & $>51.0$ & $\mathrm{~V}$ & 55.8 & $\mathrm{~V}$ & $50-55$ & $\mathrm{~V}$ & 55 & $\mathrm{v}$ & 90 & $\mathrm{~V}$ & 92 & $\mathrm{~V}$ \\
\hline 2 & $\mathrm{SiO}_{2}$ & $\begin{array}{c}0.25- \\
0.5\end{array}$ & $<1.2$ & $\mathrm{~V}$ & 0.96 & $\mathrm{x}$ & - & - & 0.1 & $\mathrm{v}$ & - & - & 2 & $\mathrm{X}$ \\
\hline 3 & $\mathrm{Al}_{2} \mathrm{O}_{3}$ & $\begin{array}{c}0.5- \\
0.9 \\
\end{array}$ & $<0.9$ & $\mathrm{v}$ & 0.14 & $\mathrm{v}$ & 0.95 & $\mathrm{~V}$ & 0.1 & $\mathrm{v}$ & - & - & 1 & $\mathrm{v}$ \\
\hline 4 & $\mathrm{MgO}$ & - & - & - & 0.15 & $\mathrm{X}$ & 2 & $x$ & 0.4 & $\mathrm{X}$ & 4.5 & $x$ & 1.75 & $x$ \\
\hline 5 & $\mathrm{Fe}_{2} \mathrm{O}_{3}$ & 0.167 & - & - & 0.04 & $\mathrm{~V}$ & 2.47 & $\mathrm{~V}$ & - & - & 1.5 & $\mathrm{~V}$ & 1 & $\mathrm{~V}$ \\
\hline 6 & $\mathrm{P}$ & - & - & - & - & - & - & - & - & - & - & - & 0.02 & $\mathrm{X}$ \\
\hline 7 & $\mathrm{P}_{2} \mathrm{O}_{5}$ & 0.915 & - & - & - & - & - & - & - & - & - & - & - & - \\
\hline 8 & $\mathrm{CO}_{2}$ & - & - & - & - & - & - & - & - & - & 55.8 & $\mathrm{x}$ & - & - \\
\hline 9 & $\mathrm{Ag}_{2} \mathrm{O}$ & 0.67 & - & - & - & - & - & - & - & - & - & - & - & - \\
\hline 10 & Kadar Air & & $<5$ & $\mathrm{~V}$ & - & - & 40 & - & - & - & - & - & - & - \\
\hline
\end{tabular}

Peta Topografi dan Peta Penyebaran Mineral Bukit Tui dapat dilihat pada Gambar 7 dan Gambar 8 dibawah ini.

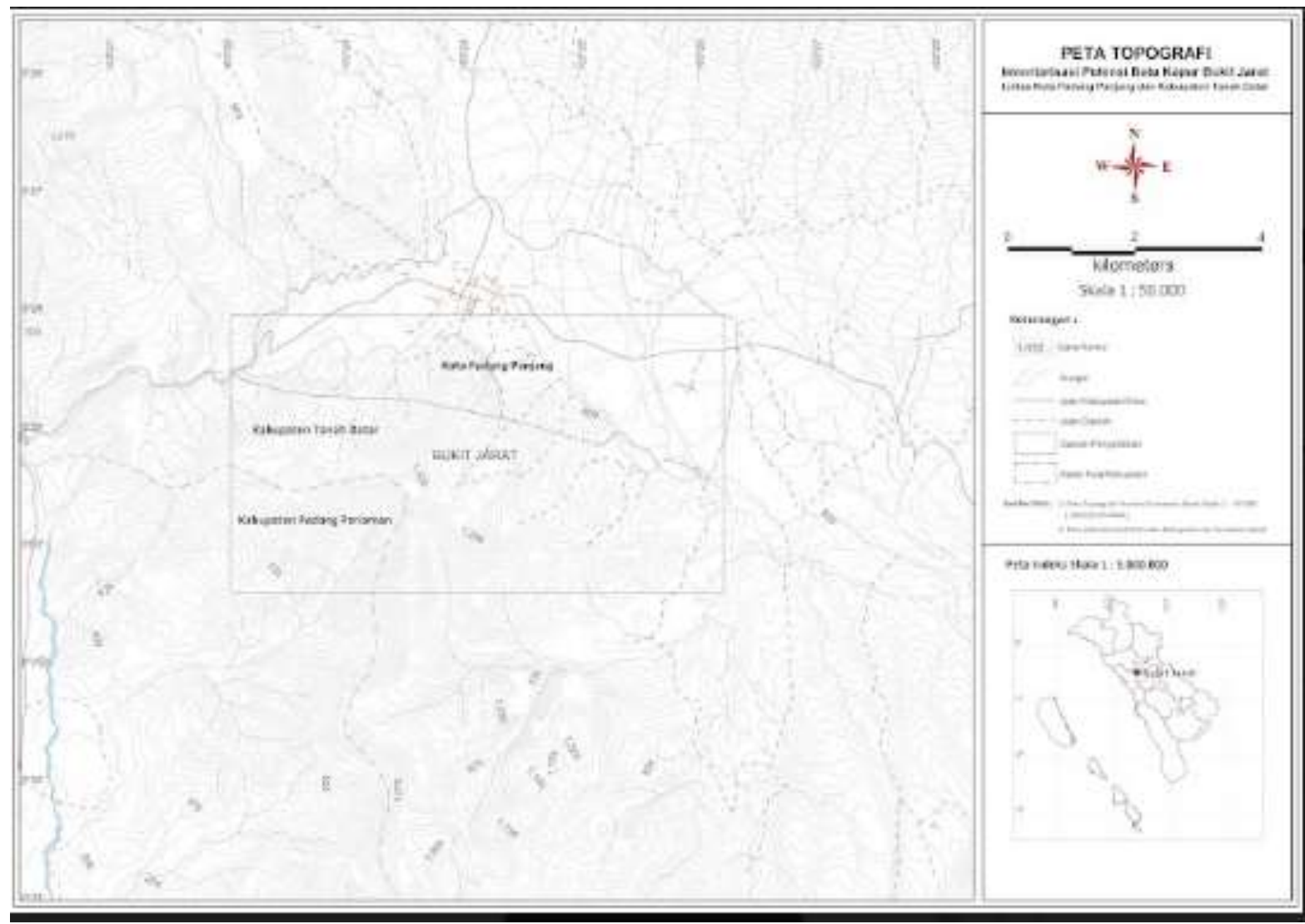




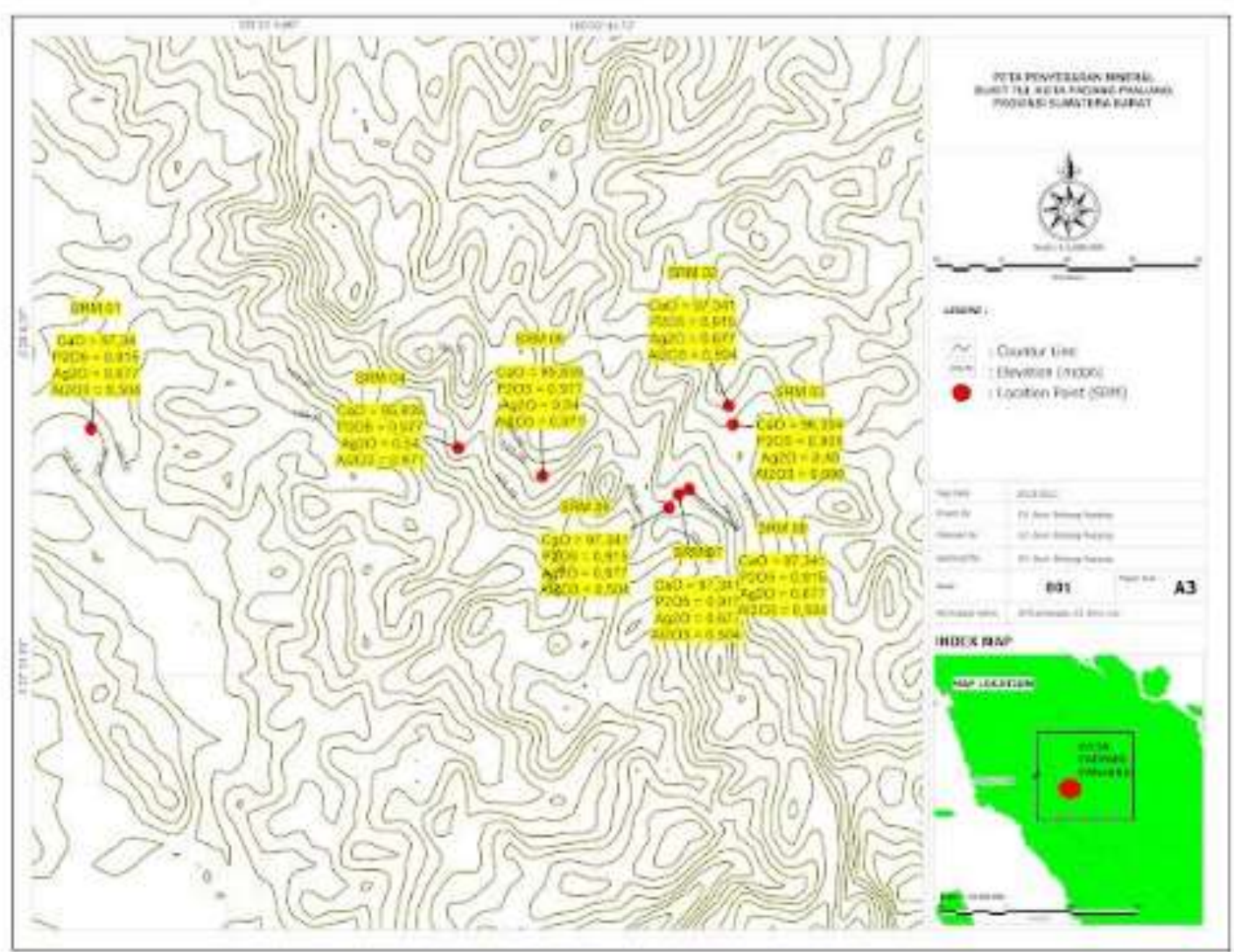

Gambar 8. Peta sebaran mineral bukit tui

\section{SIMPULAN}

Berdasarkan hasil penelitian, disimpulkan bahwa:

1. Kandungan unsur yang dimiliki oleh batu gamping Bukit Tui berdasarkan pengujian dengan metode XRF menunjukkan didominasi oleh unsur $\mathrm{Ca}(97,92 \%)$ kemudian juga mengandung unsur $\mathrm{Ag}(0,7 \%)$, unsur $\mathrm{Al}(0,3 \%)$ dan $\mathrm{Si}(0,1 \%)$ sedangkan dari pengujian dengan metode XRD menunjukkan didominasi oleh senyawa $\mathrm{CaO}(97,34 \%), \mathrm{P}_{2} \mathrm{O}_{5}$ $(0,95 \%), \mathrm{Ag}_{2} \mathrm{O}(0,627 \%)$ dan $\mathrm{Al}_{2} \mathrm{O}_{3}(0,504 \%)$. Dari niai XRD dan standar penggunaan batu kapur menurut beberapa requirement industri maka batu gamping Bukit Tui bisa dimanfaatkan pada industri baja, industri kaca, industri semen, industri gula, bata silika dan kokas.

2. Sedangkan kandungan unsur yang diproleh dari XRF digunakan untuk pembuatan peta penyebaran mineral batu gamping di Bukit Tui.

\section{DAFTAR PUSTAKA}

Apriliani, N. F., Baqiya, M. A., \& Darminto. 2012. Pengaruh Penambahan Larutan MgCl2 Pada Sintesis Kalsium Karbonat Presipitat Berbahan Dasar Batu Kapur Dengan Metode Arbonasi. Jurnal Sains dan Seni ITS.Vol. 1 No. 1.

Arif, S \& Jamarun, N. 2009. Studi Pembentukan Precipitated Calcium Carbonate (pcc) Dari Batu Kapur Alam Sumatera Barat. Ringkasan dan Summary no. 120, 1-2.

Badan Perencanaan Penelitian dan Pengembangan Daerah Kota Padang Panjang. 2019. Kajian Peluang dan Potensi Industri Kapur di Kota Padang Panjang. 
Dinas Energi dan Sumber Daya Mineral. 2015. Laporan Inventarisasi Potensi Batukapur Bukit Jarat Lintas Kota Padang Panjang dan Kabupaten Tanah Datar Provinsi Sumatera Barat.

Garinas, Wahyu. 2019. Karakteristik Batu Kapur Dalam Negeri Untuk Bahan Baku Pendukung Pengolahan Bijih Besi/Baja. Prosiding TPT XXVIII PERHAPI, (online), 3338, (http://prosiding.perhapi.or.id/index.php/prosiding/article/view/47/115) diakses 19 Agustus 2019.

Munasir, dkk. 2012. Uji XRD dan XRF Pada Bahan Mineral (Batuan dan Pasir) Sebagai sumber Material Cerdas $\left(\mathrm{CaCO}_{3}\right.$ dan $\left.\mathrm{SiO}_{2}\right)$. Jurnal Penelitian Fisika dan Aplikasinya (JPFA). Vol. 2. No.1. 